\title{
How to solve a crisis of legitimacy?:
}

\section{Empirical insights into the WTO Public Forum}

\begin{abstract}
Anne Reiff
Anne Reiff, 24, is a graduate student at Goethe University of Frankfurt in the Master Programme "International Studies/Peace- and Conflict Research". She has a Bachelor degree of Bremen University in "Political Science" since 2013. She worked several times as student research assistant, currently for Professor Nicole Deitelhoff. Anne's main research interests are North-South relations, IR theory, Latin American politics, power and resistance.
\end{abstract}

\begin{abstract}
Who participates in the discourse of legitimation taking place in the WTO Public Forum and how do the participants evaluate the World Trade Organization (WTO)? This paper offers two empirical insights into the phenomenon of Global Governance. Firstly, the discourse of legitimation is analyzed with a quantitative text analytical tool. Secondly, as the framework of the discourse is a forum founded by the WTO to start dialogue with civilsociety after the crisis of legitimacy in the 1990s, it sheds light on a strategy of Relegitimation. The empirical results show that (1) the discourse in the forum is "emptyingout" as NGOs are largely replaced by Academia and national politicians and (2) that it is limited by power inequalities between the actors.
\end{abstract}

Keywords: Global Governance; International Organizations; Legitimacy; Legitimation; NGOs; Power; Quantitative text analysis; World Trade Organization (WTO). 


\section{Introduction}

It has become quite popular among International Economic Organization to found Forums for discussion with Civil Society. Besides the World Trade Organization, at least World Bank and IMF, G8/G20 and the OECD have implemented one ${ }^{69}$. The WTO Public Forum was founded in 2001 in order to start the dialogue with civil society after example of a Global Governance Institution: it invites 1.) a wide range of actors, from NGOs and Politicians to Corporations for 2.) problem-solving as it shall prevent another crisis of legitimacy.

Apart from the functional arguments for multi-actor-cooperation, the inclusion of different actors especially from the civil-society was attributed a big potential of democratization (e.g. Esty 2004). Global Governance thereby delivered just what international elites and researchers were both desperately looking for: legitimacy for the international system. However empirical evidence for this potential was widely lacking.

This paper gives an empirical insight into the legitimation discourse taking place in the WTO Public Forum from 2007-2011 and tackles important questions like: Who is participating (and who is not)? How do the participants evaluate the WTO and on which normative grounds? The results of the discourse of legitimation are paradoxical: on the one hand the forum is clearly "emptying out" as instead of the expected audience of NGOs and Social Movements, academics and ambassadors take the lead in the discourse. On the other hand even these less critical actors are contesting the WTO and claim democracy and efficiency.

The empirical findings support the general critique on Global Governance Approaches. Their focus on horizontal decision making processes has been widely criticized for not matching the reality of international relations (e.g. Deitelhoff 2012: 67), as it does not take into account global power inequalities (Brand et al. 2000:47). But by ignoring the huge power inequalities that characterize the WTO, neither the WTO Public Forum nor the discourse of legitimation can be understood properly. The strategic design of the Forum for example, reinforces existent power inequalities between the WTO and the participants, between different civil society actors and between North and South.

The paper is structured as followed: After the introduction, the second chapter describes the "Opening Up" of the WTO after the "Battle of Seattle" in 1999 in ways of Transparency and Participation and puts the WTO Public Forum into context. The third chapter presents in 3.1 the theoretical and methodological grounds of the analysis; the "Grammar of Legitimation" from Nullmeier et al. (2010), a text analytical method for empirical legitimation research. In 3.2 a short

\footnotetext{
${ }^{69}$ World Bank and International Monetary Fund found the annual „Spring Meeting” with Civil Society, G8/G20 organize "Civil8/Civil20" and the OECD hold the" OECD Forum".
} 
description of the design of the WTO Public Forum and its general participation trends are outlined. 3.3 contains the core of the paper: the empirical analysis of the statements of legitimation in the Forum. The level of legitimation (how positive/negative are the evaluations?), the different groups of speakers (e.g. NGO/WTO; North/South) and the normative grounds on which the evaluations are done (Input/Output; democratic/non-democratic) are analyzed. The conclusion sums up the findings and gives future research perspectives.

\section{The "Opening Up" of the WTO after Seattle}

Since the 1990s, a lot of international Organizations face criticism and protest from the Global Civil Society. But it is the World Trade Organization (WTO), which became the prime example of an International Organization in a crisis of Legitimacy, since the so called "Battle of Seattle" from 1999. The street protest with 30.000- 60.000 participants led to the break-down of the Ministerial conference in Seattle and generated an enormous attention by media and also by researchers. The latter analyzed since then extensively the lack of legitimacy of the WTO (e.g. Steffek/Ehling 2008; Dingwerth et al. 2011) and presented possible solutions (e.g. Kapoor 2004; Esty 2002).

Based on this literature, the responses of the WTO to the frequent claim for an "Opening Up" after Seattle shall be presented at this point. Thus, the discourse of legitimation concerning the WTO and its frame of the WTO Public Forum can be put into context.

"Opening Up" shall mean transparency of processes and decisions of the WTO on the one hand. On the other hand it also implies more participation of non-state actors; in the Ministerial Conferences (the highest decision-making organ of the WTO), in the dispute-settlement mechanism and in the thematic committees.

The WTO did not really have another choice than responding to some of the claims of Civil Society, in order to prevent another attention-grabbing protest in the future. Rhetorically this concern can be seen in a speech hold by the Director-General at that time, Mike Moore, in front of the House of Commons in 2000:

"To survive and to be effective, structures have to be underpinned by the support of the people. It seems at the moment that this is singularly lacking. As demonstrated by Seattle, Davos, and now at every international gathering, many people feel that decisions which are having a fundamental impact upon their lives are devised behind closed doors. [...] If the WTO is to succeed, it must reinforce its democratic credentials. It must engage the confidence and the support of civil society, it 
must respond to their needs and interests, and it must be answerable for the decisions that are made." ${ }^{\prime} 0$

If the WTO actually lived up to this promises will be presented briefly. For an "OpeningUp" in ways of transparency, the WTO made all official documents available (including documents from the Dispute-Settlement-Mechanism and GATT-documents) on their website, which is generally seen as user-friendly (Steffek/Ehling 2008: 98; Dingwerth at al. 2011: 137). The WTO-Secretary circulates position papers, organizes informative meeting and in particular briefings ahead of the ministerial meetings. In terms of participation, non-state actors can be accredited as observers for the ministerial conferences and hand in civil society statements, so called "amicus curiae briefs", in the dispute-settlement-mechanism (Van Bossche 2008:726). In sum, the cooperation of civil society and WTO has been strengthened, but the possibilities for direct influence/lobbying remain on the national level. The fact that the WTO "opened-up" much less than for example the UN, is explained by Steffek/Kissling (2006:20-28) with the lack of "Pulling-factors" for the WTO. As a member-based IO with a small bureaucratic apparatus, the organization has no interest at any stage of the "policy cycle" to cooperate with civil society. The policies to enhance transparency and participation that were mentioned above, has to be seen therefore as direct responses to the crisis of legitimacy in the late 90s (Steffek/Kissling 2006: 26f).

Likewise, the foundation of a Public Forum was already outlined in the guidelines of the General Council from 1996, but it was only after the protests of Seattle that the format was changed from a plenary meeting with hundreds of participants in one room to the current design of parallel panels with room for discussion (Van Bossche 2007: 728f). Van Bossche (2007:731) summarizes the goals of the WTO Public Forum:

"The [...] public forums do not lead to any specific outcomes, such as, for example, a civil society statement to the WTO Ministerial Conference or General Council. [...] Their aims have been more modest, namely to facilitate the exchange of views and perspectives on WTO issues in a frank and open way and to allow participants to network and establish contacts."

The WTO Public Forum as the probably most time- and money-consuming reform after Seattle illustrates the general goal of the "Opening-Up"-strategy of the WTO: much exchange, little direct influence.

\footnotetext{
${ }^{70}$ Quelle WTO (1): http://www.wto.org/english/news_e/spmm e/spmm26 e.htm.
} 


\section{3. "Civilized discourse" ${ }^{71}$ or "Calling for the shutting down"72?}

Text Analysis of the Publications of the WTO Public Forums 2007-2011

\subsection{How to catch legitimation? The Grammar of Legitimation (Nullmeier et al.)}

The empirical analysis of the statements made in the WTO Public Forum is done with the method of "Grammar of Legitimation" by Nullmeier et al. (2010). For reasons of limited space, only a very short overview of the theoretical and methodological background can be given at this point. The priority is to make the empirical results of Chapter 3.3 comprehensible.

The book "Precarious Legitimacies" [Prekäre Legitimitäten] by Nullmeier et al. (2010) develops an approach to grasp the dynamics of legitimation concerning international institutions just as nation-states. The approach does rely on Max Weber's descriptive understanding of legitimacy. But instead of using his concept of Legitimacy as "the willingness to obey", the authors focus on Weber's comment that legitimacy always has to be attributed. Nullmeier et al. (2010) outline a model of legitimacy, in which legitimation is the process of evaluations, which then attributes legitimacy to a political order (Nullmeier et al. 2010: 31f). To put the concrete evaluations of legitimacy in the focus of the analysis, offers on the one hand the possibility to get a differentiated viewpoint on the legitimacy of a political order (between secure and absent legitimacy). On the other hand it enables us to grasp the dynamics of legitimation processes as it understands legitimacy as a linguistic process, where the speaker and the normative grounds of their evaluations can be identified (Schneider/Nullmeier/Hurrelmann 2007: 131). This new understanding of legitimacy requires a new method, which can extract and categorize different information from a statement of evaluation: the Grammar of Legitimation.

After slightly adapting the method to the specific case of the WTO and its Public Forum, four variables are coded at each statement (Table 1). The analyzed statements are taken from the "Publications", the official summaries of the Forum, written by the different organizers of the panels. To make the analysis manageable, 27 panels have been selected from the Publications from 2007-2011, which resulted in 123 statements in total. In the description of the empirical findings only the most frequent groups of speakers and used criteria of legitimation can be taken into account.

\footnotetext{
${ }^{71}$ Cited from the opening speech of the first Forum by Mike Moore, Director-General of the WTO at that time. Available at WTO (2): http://www.wto.org/english/news e/spmm e/spmm67 e.htm (14.09.2013).

72 Cited from Aftabalam Khan, International Coordinator of the NGO Action Aid in Session 12, WTO Public Forum 2007, p 124.
} 
Table 1: Overview of all coded variables and their values

\begin{tabular}{|l|l|l|l|}
\hline $\begin{array}{l}\text { Tenor of } \\
\text { Evaluation: }\end{array}$ & $\begin{array}{l}\text { Pattern of } \\
\text { Legitimation: }\end{array}$ & $\begin{array}{l}\text { Group of } \\
\text { Speaker: }\end{array}$ & $\begin{array}{l}\text { Origin } \\
\text { Speaker: }\end{array}$ \\
\hline Legitimation & Democratic Input (DI) & $\begin{array}{l}\text { National } \\
\text { Politician }\end{array}$ & North \\
\hline $\begin{array}{l}\text { De- } \\
\text { legitimation }\end{array}$ & $\begin{array}{l}\text { Non-democratic Input } \\
\text { (NDI) }\end{array}$ & Corporation & South \\
\hline Claim & $\begin{array}{l}\text { Democratic Output } \\
\text { (DO) }\end{array}$ & NGOs & Not defined \\
\hline & $\begin{array}{l}\text { Non-democratic Output } \\
\text { (NDO) }\end{array}$ & $\begin{array}{l}\text { Academics/ } \\
\text { Think-Tanks }\end{array}$ & \\
\hline & & WTO & \\
\hline & & other IO & \\
\hline & & Audience & \\
\hline
\end{tabular}

Source: Author

\subsection{What is the WTO Public Forum?}

As Director General Mike Moore opens the first WTO Public Forum in 2001, he demands the present NGOs to distance themselves from "masked stone-throwers [...], antiglobalization dot.com types" and instead engage in the "civilized discourse" taking place in the new forum. The foundation of the forum is clearly a reaction to the protests of Seattle, but the statement shows that it never had the goal to integrate the corresponding social movements, but to divide civil society by inviting some, sympathetic actors. The strategic use of the Forum to channel the discourse can also be seen in the design; not every participant or topic is per se accepted, instead: "The WTO will select the best proposals and allocate the sessions" (WTO 3).

The WTO Public Forum is held annually in the WTO Headquarter in Geneva, where discussions take place in around 40 Panels in three days. These Panels are mainly organized by the invited organizations themselves, which have to apply with a panel proposition. The WTO selects the proposals, offers infrastructure and organizes the Opening Panels.

\section{Who participates?}

The WTO has documented the general participation in the Forum since 2009. What can be seen from the accordant documents is that the number of participants rises from 2009 until 2011 up to 1520 participants and drops in 2012 to 1359. The biggest groups of participants were NGOs, followed by Academics, National politicians and Corporations. But a closer look at the development over time points in another direction: while all groups follow a positive trend of participation, only NGOs participate less and less. Even though publications from WTO- 
representatives prefer to ignore this development (Pérez-Esteve 2012: 18), it fits perfectly into the new WTO-strategy from 2006 "to promote the participation of experts from all categories of stakeholders $[\ldots]$ in particular government officials and business representatives" (Pérez-Esteve 2012:18). In sum, the Forum has no longer NGOs as the main audience, like in the first years after Seattle.

\subsection{Empirical results of the text analysis}

\section{Tenor of Claims and Critique}

Chart 1 shows the critical tenor of the analyzed statements; De-Legitimations and Claims with almost the same share contribute more than two third of all statements. With only 36 legitimating statements, the level of Legitimation results in $29 \%$.

\section{Chart 1: Level of Legitimation ( $N=123)$}

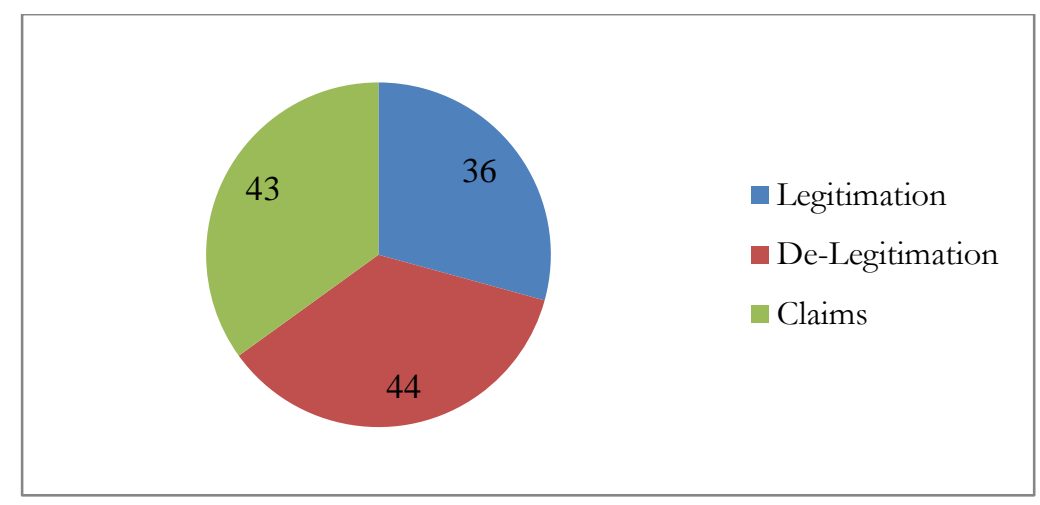

Source: Author

A very critical statement and its reaction shall help to get an idea about the scope of the evaluations. André Misiekaba, Parliamentarian from Surinam states, statement 105:

"a decade and a half of the WTO had delivered a world with closed, non-transparent and unfair trade, a growing gap between rich and poor, and unmet engagement from developed countries. $\mathrm{He}$ asked whether this was the accountability the WTO needed to deliver" (Publication 2010, Session 19).

As a defense, Gabrielle Marceau, Legal Affairs Division of the WTO, responded "that this was a moral question and that neither the WTO nor any international forum had a responsibility for wealth distribution" (Publication 2010, Session 19).

In sum, there is a wide scope of evaluations, from enthusiasm about the accomplishments of the WTO to fierce critique of its contribution to global Injustice. The general level of Legitimation in the discourse remains low. 


\section{Northern Academics and Southern Politicians}

But which groups of Speakers are dominant in the discourse and what role does the origin (North - South) play? Chart 2 provides the crucial information about the bias of participation: First, the number of statements per group is very unequally distributed. The Group "Academics/Think-Tanks" is dominating the discourse in the Forum, followed by "National Politicians". NGOs only make the same amount of evaluations as the WTO itself. Second, the Southern speakers are focused on very few groups of speakers. While nearly all national Politicians are from the Global South, they are highly underrepresented within the Academics/Think-Tanks. Only NGOs have a balance of North-South speakers.

\section{Chart 2: Number of Statements per Group and Origin}

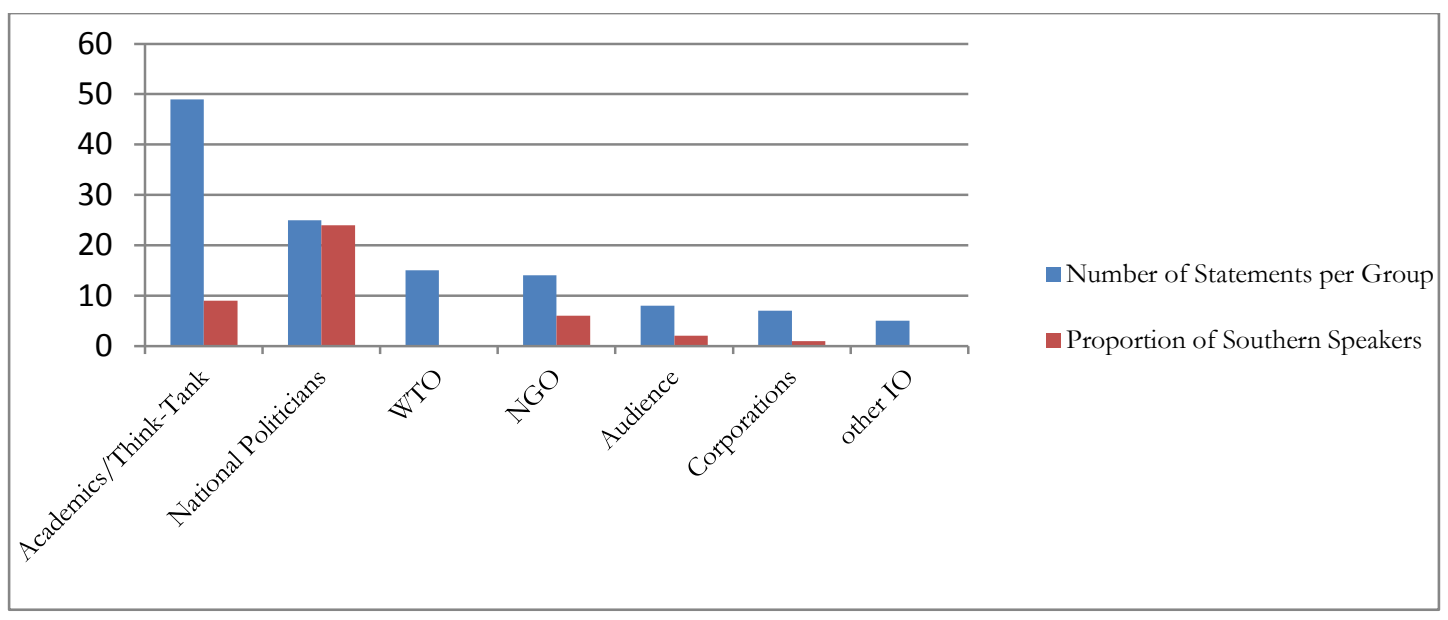

Source: Author

The fact that Academics/Think-Tanks are the most present group in the discourse of legitimation is surprising. In the academic literature on the "Opening-Up" of the WTO, researchers hardly see themselves as actors of civil society or as the addressee of the WTO reforms. The high number of statements by national politicians seems to be illogical: as a member-based organization who decides by consensus, the WTO provides more direct channels of communication and influence for the member-states representatives than a yearly held forum. Nearly all of them being Southern politicians, it becomes clear how little weight they give their own voice in the WTO decision-making process. The WTO Public Forum seems to be an alternative way to be heard. The fact that the majority of the Southern speakers can be found in this group could be explained by the limited capabilities of other Southern speakers to travel to Geneva for the Forum, while the political elites from the South do not have these limitations. The ambassadors might even be situated in Geneva anyways. 
Concerning the level of Legitimation per Group of Speakers, the picture stays diverse. Academics/Think-Tanks assess the WTO critically by making many claims. They argue on a high information level, even taking into the account the concept of "Legitimacy" itself in the claims, like in statement 21 from Mayur Patel, Global Trade Governance Project Oxford: "After the bitter experience of not understanding the implications of new rules negotiated during the Uruguay Round, more informed negotiations [...] would strengthen the WTO's Legitimacy" (Publication 2007, Session1).

National Politicians instead evaluate the WTO in a much more positive way. Some statements are even more enthusiastic than the Self-Legitimation by the WTO, like statement 67/68/69 from Sergio Abreu, Senator and former Foreign Minister of Uruguay shows:

"Mr. Abreu pointed to the WTO as the only organization today, whose structures has not been questions, whose decisions are based on consensus and whose agenda moves in line with -and sometimes ahead of- world events" (Publication 2009, Session High Level Panel).

As expected the speakers from the WTO itself are busy with self-legitimation; their statements have the highest level of legitimation, only two are not legitimating ones.

From the named groups, NGOs take the most critical view on the WTO, only one statement is positive. Alexandra Chandra from Trade Knowledge Network, Indonesia points out in statement 91: "Civil Society groups in Indonesia take a cynical view of the WTO; they like the WTO because they do not think it does very much by way of market opening" (Publication 2010, Session 11).

Mike Moore's announcement of a "civilized discourse" taking place in the WTO Public Forum seems to limit the space for radical statements, questioning the institution as such. But since 2011, with the deadlock of the negotiations of Doha, more and more speakers see the WTO in an existential crisis. Consultant Jaques Carles, Paris, claims in statement 121 "the WTO is negotiating as if it was still in the 1950s, but now it is 2011. He suggested that maybe it is time to remove the agriculture component from the WTO and create a World Agriculture Organization" (Publication 2011, Session 13). Also northern diplomats, otherwise supportive, like Michaela Dodini, Permanent Representative of the EU to the WTO criticizes: "There needs to be a serious discussion on what is not working and why, as the time for "business as usual" is definitely over" (Publications 2011, Session 19).

\section{Democracy and Efficiency}

The grammar of legitimation seeks to extract who raises voice in a discourse and how positive or negative the tenor is. But its particular contribution to empirical legitimation research 
is that it can analyze the normative criteria an evaluation (legitimation/de-legitimation/claim) is based on. Table 2 lists in the first column the four patterns of legitimation and its most frequent criteria, the second column contains the distribution of statements per pattern in numbers and percentage and the third column adds the level of legitimation (share of positive statements) of each pattern.

Table 2: Patterns - Level of Legitimation

\begin{tabular}{|c|cc|c|}
\hline & \multicolumn{2}{|c|}{$\begin{array}{c}\text { Distribution of Pattern } \\
\text { of Legitimation } \\
\mathrm{n}\end{array}$} & $\begin{array}{c}\text { Level of Legitimation per } \\
\text { Pattern: } \\
\%\end{array}$ \\
\hline Democratic Input (DI) & 68 & $55,28 \%$ & $30,88 \%$ \\
North-South-Justice & 17 & & \\
Transparency & 16 & \\
Participation (non-state actors) & 12 & $18,8 \%$ \\
\hline Non-democratic Input (NDI) & 11 & \\
Capability/agency & 7 & & \\
Expertise & 2 & & \\
\hline Democratic Output (DO) & 8 & $6,94 \%$ & \\
Contribution to public good & 4 & & \\
Democratic empowerment & 3 & & \\
\hline Non-democratic Output (NDO) & 36 & $29,27 \%$ & \\
Efficiency & 17 & & \\
Distributive Justice & 8 & & \\
Relevant agenda & 7 & & \\
\hline
\end{tabular}

Source: Author

The table shows that the pattern "Democratic Input" is used the most frequently (more than half of all analyzed statements), followed by the pattern of "Non-democratic Output", which is used almost in a third of the evaluations. The most frequently used criteria of the DIpattern reflect the two conflict lines after Seattle, described in Chapter 2: Opening Up (Transparency and Participation) and North-South-Justice. Still, it is noteworthy that the WTO with its technocratic mandate is now mainly evaluated by democratic criteria. The pattern of "Non-democratic-Output", especially the criteria of "Efficiency" comes closest to the "traditional" criteria to evaluate International Organizations: Fulfilling the Mandate. Even though democratic criteria dominate the discourse in the Forum, they still play a significant role for evaluation. Especially the deadlock of Doha negotiations for years could be a reason for the 
criticism of efficiency of the WTO. Concerning the level of legitimation, both democratic patterns (Input and Output) are used more frequently for legitimating statements than the two non-democratic ones. Still the difference is small; especially the most common patterns (DI and NDO) only have a level of legitimation of around $30 \%$. In that sense, no pattern or underlying criteria is functioning as a resource of legitimation for the WTO.

As a last point on the pattern of legitimation, it is also worth noticing that the different groups of speakers all established the same patterns for their evaluations. Even though their level of legitimation differs a lot, from highly legitimating like the WTO-Speakers to very critical like the NGOs, they all use mainly the pattern of "Democratic-Input" and "Non-democraticOutput" to evaluate the WTO.

\subsection{Summary of empirical findings}

The empirical findings on the discourse of legitimation can be summarized in 5 points: First, the discourse of legitimation is characterized by a low level of legitimation (less than a third of the statements are legitimating). For a Forum that was set up for discussion about the WTO that does not come as a surprise. After the widespread protests at the end of the 90s, even a more critical tenor could be expected. This negative tenor of the statements relies mainly on the de-legitimations and claims by the group of Academics/Think-Tanks and NGOs, while the W'TO in particular and also national Politicians seek to strengthen the W'TO's legitimation.

Second, the discourse of legitimation in the Forum is clearly dominated by Academics/Think-Tanks from the Global North, followed by national Politicians from the Global South with half so many statements. WTO speakers and NGO representatives participate less frequent in the discourse; the participation of corporations and other IOs is negligible.

Third, the general trend of participation is therefore confirmed: NGOs are no longer the main actors of the Forum, like in 2001, when Mike Moore addressed his Opening-Speech to them. Those NGOs that opted for the "Civilized Discourse" have either lost their interest in the forum or they are strategically replaced by other (less critical) audiences.

Fourth, the analysis shows the strong attempt of self-legitimation by the WTO, which is confronted since 2011 with the deadlock of Doha-negotiations with more fundamental criticism concerning the whole institution. Still, the "calling for the shutting down" stands alone; instead a lot of the critique is formulated in diplomatic claims.

Fifth, the evaluation of the legitimation of the WTO is mostly done on grounds of democratic-input criteria, like North-South Justice, Transparency and Participation. But also the pattern of Non-democratic Output, in particular the criterion of "Efficiency" plays a significant 
role. Both patterns have become established for all the groups of speakers, regardless their different level of Legitimation.

\subsection{Conclusion}

The empirical analysis gives proof to the assumption some researchers already had: the Forum is "emptying-out" (e.g. Deitelhoff 2012: 72f). While it was never meant to include those parts of civil society that are highly critical (e.g. the various social movements from the "Battle of Seattle"), but instead divide the coalitions of the protests of the 90s (O’Brien et al.:208-209, 222), even the sympathetic NGOs are less and less present in the Forum and academics and national politicians/ambassadors take their place. One reason could be the frustration about the very limited influence, outlined in Chapter 2; Greenpeace International stopped their campaign due to this reason (Steffek 2012: 235). Another reason could be the strategic change of audience since 2006 by the WTO to national politicians and corporations (Pérez Esteve 2012). But the analysis of the discourse shows that nonetheless, the tenor of the discourse is highly critical and claims especially for a more democratic WTO are raised. The importance of power inequalities do not only have impact on the participation of civil society, but the fact that nearly all politicians participating in the Forum come from the Global South, illustrates their marginalization in the decision-making processes of the WTO.

The paper raises several issues for future research. First, the fact that a civil society forum is clearly dominated by academics calls for empirical work (E.g.: What is the role of academics in international discourses?) and normative evaluations (E.g.: Is legitimacy strengthened because academics represent the civil society/because of their expertise or weakened because of the widening gap of information?). Second, a comparison of the various Forums of International Economic Institutions including the design, participation and the discourse would be very interesting. Third, a closer look at the patterns of legitimation, in particular the combination of the criteria of democracy and efficiency could be crucial for the evaluation of International Organizations. Tony McGrew (2001:42) gives an outlook for the WTO:

"The battle of Seattle framed the future of the WTO in terms of a stark choice between a democratic and an effective WTO. A decade later neither alternative has been realized. [...] Rather the existential crisis of the WTO is ultimately concerned with how these aspirations can and must be combined." 


\section{References}

Brand, Ulrich/Brunnengräber, Achim/Schrader, Lutz/Stock, Christian/Wahl, Peter (2000): Global Governance. Alternative to a neo-liberal globalization? [Global Governance. Alternative zur neoliberalen Globalisierung?] Münster, Westfälisches Dampfboot.

Deitelhoff, Nicole (2012): Deliberation and Opposition in the context of transnational policies of legitimation. [Deliberation und Opposition im Kontext transnationaler Legitimitätspolitik]. In: Leviathan, Special Edition 27: The rise of policies of legitimation [Der Aufstieg der Legitimitätspolitik], 63-80.

Dingwerth, Klaus et al. (2011): Postnational democracy [Postnationale Demokratie]. Chapter 5. Wiesbaden: VS Verlag für Sozialwissenschaften.

Esty, Daniel C. (2002): The World Trade Organization's legitimacy crisis. In : World Trade Review (2002), 1(1), 7-22.

Kapoor, Ilan (2004): Deliberative democracy and the WTO. In: Review of International Political Economy, 11(3), August 2004. 522- 541.

McGrew, Tony (2011): After Globalisation? WTO reform and the new global political economy. In: Cottier, Thomas/ Elsig, Manfred (Eds.), Governing the World Trade Organization. Cambridge: Cambridge University Press, 20- 46.

Nullmeier, Frank/ Biegon, Dominika/ Gronau, Jennifer/ Nonhoff, Martin/ Schmidtke, Henning/ Schneider, Steffen (2010): Precarious Legitimacies. Justification of rule in the postnational constellation. [Prekäre Legitimitäten. Rechtfertigung von Herrschaft in der postnationalen Konstellation]. Frankfurt/ New York: Campus Verlag.

O’Brien, Robert/ Goetz, Anne Marie/ Aart Scholte, Jan/ Williams, Marc (2000): Contesting Global Governance. Multilateral Economic Institutions and Global Social Movements. Cambridge: Cambridge University Press.

Pérez-Esteve, Maria (2012): WTO rules and practices for transparency and engagement with civil society organizations. Staff Working Paper ERSD- 2012-14. Text abrufbar unter: http://www.wto.org/english/res e/reser e/ersd201214 e.pdf (Zugriff am 14.09.2013).

Schneider, Steffen/ Nullmeier, Frank/ Hurrelmann, Achim (2007): Exploring the Communicate Dimension of Legitimacy: Text Analytical Approaches. In: Hurrelmann, Achim/ Schneider, Steffen/ Steffek, Jens (Hrsg.), Legitimacy in an Age of Global Politics. Hampshire: Palgrave Macmillan, 126- 155.

Steffek, Jens (2012): Conflicting mandate, criticism of liberalism and the politicization of GATT and WTO. [Mandatskonflikte, Liberalismuskritik und die Politisierung von GATT und WTO.] In : Zürn, Michael/ Ecker- Ehrhardt, Matthias (Hrsg.), Die Politisierung der Weltpolitik, Berlin: Suhrkamp Verlag, 213- 239. 
Steffek, Jens/ Ehling, Ulrike (2008): Civil Society Participation at the Margins: The Case of WTO. In: Steffek, Jens/ Kissling, Claudia/ Nanz, Patrizia (Hrsg.), Civil Society Participation in European and Global Governance. Hampshire: Palgrave Macmillan, 95- 115.

Steffek, Jens/ Kissling, Claudia (2006): Civil Society participation in international governance: the UN and the W'TO compared. TransState working papers, No. 42. Abrufbar unter: www.hdl.handle.net/10419/24955 (Zugriff am 05.06.2013).

Van Bossche, Peter (2008): NGO Involvement in the WTO: A comparative perspective. In: Journal of International Economic Law 11(4), 717- 749.

W'TO (1):

http://www.wto.org/english/news e/spmm e/spmm26 e.htm (Zugriff am 28.05.13).

WTO (2):

http://www.wto.org/english/news e/spmm e/spmm67 e.htm (Zugriff am 14.09.2013).

WTO (3):

http://www.wto.org/english/news e/news13 e/pfor 22 may13 e.htm (Zugriff am 18.09.2013).

WTO Public Forum 2007, Publication:

http://www.wto.org/english/res e/booksp e/public forum06 e.pdf (15.09.2013).

WTO Public Forum 2008, Publication:

http://www.wto.org/english/res e/booksp e/public forum08 e.pdf (15.09.2013).

WTO Public Forum 2009, Publication:

http://www.wto.org/english/res e/booksp e/public forum09 e.pdf (15.09.2013)

WTO Public Forum 2010, Publication:

http://www.wto.org/english/res e/booksp e/public forum10 e.pdf (15.09.2013).

WTO Public Forum 2011, Publication:

http://www.wto.org/english/res e/booksp e/public forum11 e.pdf (15.09.2013).

\section{Appendix (List of all coded statements)}

(Abridged due to spatial limitations. Please, contact the author.) 